\title{
Protein Mutations and Stability, a Link with Disease: The Case Study of Frataxin
}

\author{
Rita Puglisi (1)
}

check for updates

Citation: Puglisi, R. Protein Mutations and Stability, a Link with Disease: The Case Study of Frataxin. Biomedicines 2022, 10, 425. https://doi.org/10.3390/ biomedicines10020425

Academic Editor: Marie-Pierre Golinelli-Cohen

Received: 28 December 2021

Accepted: 25 January 2022

Published: 11 February 2022

Publisher's Note: MDPI stays neutral with regard to jurisdictional claims in published maps and institutional affiliations.

Copyright: (C) 2022 by the author. Licensee MDPI, Basel, Switzerland. This article is an open access article distributed under the terms and conditions of the Creative Commons Attribution (CC BY) license (https:// creativecommons.org/licenses/by/ $4.0 /)$.
UK Dementia Research Institute at the Wohl Institute of King's College London, London SE59RT, UK; rita.puglisi@kcl.ac.uk

\begin{abstract}
Protein mutations may lead to pathologies by causing protein misfunction or propensity to degradation. For this reason, several studies have been performed over the years to determine the capability of proteins to retain their native conformation under stress condition as well as factors to explain protein stabilization and the mechanisms behind unfolding. In this review, we explore the paradigmatic example of frataxin, an iron binding protein involved in $\mathrm{Fe}-\mathrm{S}$ cluster biogenesis, and whose impairment causes a neurodegenerative disease called Friedreich's Ataxia (FRDA). We summarize what is known about most common point mutations identified so far in heterozygous FRDA patients, their effects on frataxin structure and function and the consequences of its binding with partners.
\end{abstract}

Keywords: Fe-S proteins; Fe-S cluster biogenesis; genetic diseases; missense mutations; protein stability

\section{Introduction}

Several pathologies are linked to proteins with anomalous conformations. They can be distinguished into two categories: toxic gain-of-function and loss-of-function diseases. Neurodegenerative diseases characterized by metastable proteins prone to form toxic aggregates, i.e., soluble oligomers and fibrillar amyloid deposits, belong to the first group. The determination of protein stability may provide a measure of the propensity of the protein to aggregate. There are, however, several cases in which aggregation is not clearly linked to reduced stability. For instance, it has been shown that the ALS mutants of $\mathrm{Cu}$, the $\mathrm{Zn}$-superoxide dismutase apoprotein, do not all share reduced stability [1]. Additional factors must thus be identified and investigated to explain protein aggregation, for example, the lowering of the kinetic activation barrier for unfolding [2], internal dynamics and metal ion coordination [3,4], as well as environmental conditions, such as oxidative stress, $\mathrm{pH}$ shift and osmotic shock. In the second group of diseases, proteins are not functional or metastable and prone to degradation because of specific mutations. In this review, we examine this second group by taking the paradigmatic example of Friedreich's ataxia (FRDA). Frataxin, the protein implicated in FRDA, has a role in the Fe-S cluster biogenesis and possesses a well-defined structure [5]. We aim to summarize what is known about this protein, to date. We will linger especially on its mutants and their correlation to FRDA. We propose a classification according to their effect on the folding, stability or function. We apologize in advance to the colleagues who have not been cited and suggest the reading of other recent reviews that complement the information reported here [5-9].

\section{The Molecular Bases of Protein Stability}

It can be generally assumed that proteins occur in two states: folded and unfolded. Protein stability is the capability of a protein to retain its native conformation under stress condition, such as the departure from room temperature, high pressure or the presence of denaturing chemicals. For all proteins, the transition between folded and unfolded species 
may occur both at temperatures higher and lower than room temperature and $T_{m}$ and $\mathrm{T}_{\mathrm{c}}$, the two temperatures at which there is the equilibrium between equal populations of the two species, are generally referred to as hot and cold unfolding temperatures, respectively [10]. The folded conformation is more populated in the temperature range between the two temperatures of melting, whereas unfolded forms predominate at temperatures higher than $T_{m}$ or lower than $T_{c} . T_{c}$ is rarely determined since water usually freezes before this transition. On the other hand, the heat denaturation temperature, $\mathrm{T}_{\mathrm{m}}$, is commonly taken as the best description of thermal stability, and a protein with a higher $\mathrm{T}_{\mathrm{m}}$ is usually considered as more thermally stable. Strictly speaking, it corresponds to assuming a proportionality between $\Delta \mathrm{T}_{\mathrm{m}}$ and $\Delta \Delta \mathrm{G}$, which is true only if the corresponding stability curves at the two temperatures are parallel [11]. When this is not the case, the value of $\mathrm{T}_{\mathrm{m}}$ describes only the thermal resistance. Proteins are generally active at temperatures up to their $\mathrm{T}_{\mathrm{m}}$ and down to their $\mathrm{T}_{\mathrm{c}}$, unless other effects take place, e.g., aggregation.

Over the years, a combination of different physical and chemical reasons has been identified to explain thermostability. A comprehensive description at the molecular scale of the mechanisms responsible for thermal and cold stability is extensively discussed in a review by Pucci and Rooman [12]. The hydrophobic effect constitutes the main driving force of protein folding and results from the tendency of hydrophobic amino acids to cluster together [13]. The two transitions are linked to the opposing changes in conformational entropy: the increase connected to the high temperature transition corresponds to a decrease in the low temperature transition. This difference has often puzzled many researchers, but it was made clear by Privalov [14] that the hydration of apolar side chains in the hydrophobic core compensates for this difference at a low temperature. In other words, the cold transition is mainly related to the weakening of the hydrophobic effect that becomes unfavorable below a certain temperature compared to hydrophobic-water interactions, whereas the hot denaturation is associated with an increment of conformational fluctuations [15]. Additionally, salt bridges contribute to improve heat resistance by lowering the de-solvation penalty at high temperatures [16,17], as well as the interactions between aromatic residues [18]. The formation of higher-order oligomeric structures is a possible strategy for protein thermal adaptation [19].

The knowledge of the difference in free energy between the folded and unfolded forms $(\Delta G)$ and the temperature of transition, $T_{m}$, allow for a complete characterization of the thermal properties of a protein. However, the accurate determination of all thermodynamic parameters is only possible when both warm and cold denaturation are determined [20,21]. This information can be obtained by the observation of the folded fraction variation in the presence of a perturbing agent (e.g., temperature, pressure or denaturants). Monitoring can be performed using a variety of spectroscopic techniques. One of the most widely used techniques is circular dichroism (CD) spectroscopy in the 190-260 range, which reports changes in the content of secondary structures. Fluorescence spectroscopy is also often used to follow protein unfolding, usually exploiting the properties of the tryptophan residues. The side chains of these residues are specifically excited at $295 \mathrm{~nm}$ and their emission is sensitive to the chemical environment; it occurs at $350 \mathrm{~nm}$ when the residue experiences a polar and solvated environment, whereas it occurs at 320-340 in an apolar environment. The use of NMR spectroscopy to monitor unfolding has become progressively more important. Initially it was based on the properties of the so-called ring-current shifted peaks whose detection is strongly indicative in the folded species [22]. The measurement of the areas of these peaks in 1D NMR spectra is a sensitive way to measure folded populations, owing to the strict proportionality of peak area to concentration [23], whereas several limitations hampered the use of 2D NMR. Recently, Puglisi et al. [21] showed that 2D spectra can also be used reliably to monitor both cold and heat unfolding, and even to gather information from different parts of the protein [24].

Several studies exploiting the computational approaches have also been published to predict the temperature of thermal denaturation, $\mathrm{T}_{\mathrm{m}}$. They are based on statistical analysis [25,26], molecular dynamics [27] or machine learning methods [28]. A new theo- 
retical analysis was recently designed by Miotto et al. to predict thermal stability based on the structure only, and without any other a priori information [29].

Biologically active proteins, thought to be in a thermodynamically favorable conformation, are often marginally stable under physiological conditions [30]. Molecular chaperones assist proteins to efficiently fold by transiently shielding the hydrophobic amino acids belonging to the protein core in the native fold, but which are exposed in the non-native conformation. In the cell, the chaperones cooperate with proteostasis mechanisms that activate the degradation pathway for the misfolded protein. These defense mechanisms tend to decline during aging, facilitating the manifestation of misfolding diseases [31].

Understanding the mechanisms of protein folding is important to explain the extent to which protein thermal stability can be related to disease.

\section{Friedreich's Ataxia}

Friedreich's ataxia (FRDA) is an autosomal recessive hereditary ataxia that affects 1 individual out of every 50,000 [32]. The age at onset is usually before 25 years and the most common symptoms are the progressive ataxia of the four limbs, loss of tendon reflexes and position sense, pyramidal weakness of the legs, dysarthria, skeletal deformities (as scoliosis and pes cavus) and Babinski signs [33,34]. In addition, hypertrophic cardiomyopathy and diabetes or carbohydrate intolerance are observed in $30 \%$ of the cases $[33,35,36]$. However, the patients affected by FRDA present phenotypes that can range between different levels of severity and sometimes, if they do not meet all the essential criteria, they are classified as atypical. The disease has currently no treatment and the progression often leads to increasing disabilities and the eventual loss of independent ambulation, with most patients confined to a wheelchair by their late 20s. Death usually occurs before the age of 50 .

The genetic alteration in FRDA was localized within chromosome 9q13-q21.1 [37], which encodes a protein called frataxin. This is a highly conserved protein found in all species, from prokaryotes to eukaryotes. It is localized in the inner mitochondrial membrane [38-40] and has a role in the cellular regulation of iron homeostasis.

A (GAA) $n$ triplet repeat expansion in the first intron of the frataxin gene, originally known as X25, is the most common mutation in FRDA [32], causing frataxin deficiency. In healthy individuals, the number of repeats is in the 6-36 range, whereas in FRDA it ranges from 70 to 1700 repeats, most commonly 600-900 [5]. A higher number of repeats directly correlates with an increase in disease severity, especially decreasing the age of disease onset $[6,41]$. At the cellular level, a general iron deficiency with an increase in mitochondrial iron import and accumulation [42,43], together with an increase in ROS [44] and disruption in both heme and Fe-S cluster production [45,46], are correlated to frataxin deficiency. The impairment of the frataxin function may damage mitochondria and also increase the chance of tumor formation. Frataxin missense mutations have indeed been identified in cancer tissues where tumor-initiating cells show a higher iron uptake [47].

\section{Frataxin and Fe-S Cluster Biogenesis}

Several diseases are associated with the disruption of cellular iron homeostasis, as both iron overload and deficiency are damaging to cells. The balance of iron in biological systems is thus of fundamental importance. Organisms evolved mechanisms to modulate free iron concentrations in the cell with the formation of prosthetic groups, such as heme and Fe-S clusters. Frataxin is supposed to play a role in the iron-sulfur cluster and heme biosynthesis [6]. FRDA patients show an Fe-S cluster deficiency from the beginning of the disorder, suggesting the direct role of frataxin in the Fe-S cluster assembly [46].

The Fe-S cluster prosthetic groups are of fundamental importance for protein structure, they play a role in electron transfer, substrate binding and activation, iron and sulfur storage, regulation of gene expression and sometimes in enzyme activity [48-51]. In bacteria, there are three separate pathways for cluster production: the nitrogen fixation machinery (Nif) [52,53], the Isc machinery for most cellular needs [54,55] and the Suf machinery, which contributes under stressed conditions [56]. The Isc system components 
have orthologs with high sequence homology in eukaryotes $[50,57,58]$. The main players are a desulfurase (Nfs1 in eukaryotes, IscS in bacteria) and a scaffold protein (Isu/IscU). The desulfurase is a symmetric dimer containing PLP. This enzyme converts cysteine into alanine, providing sulfur to the scaffold protein on which the cluster is assembled [59]. Two chaperones (HscA and HscB in bacteria), with which frataxin has an identical phylogenetic distribution [60], are supposed to help the releasing of the Fe-S cluster from the scaffold protein to the acceptor [61]. However, HscB has recently been shown to also interact with the desulfurase, opening a new question on its role [62]. Electrons necessary for sulfur liberation are provided by a ferredoxin ( $\mathrm{FdX}$ in bacteria and Yah1 with the ferredoxin reductase Arh1 in eukaryotes) [57]. IscA/Isa is able to bind the nascent Fe-S cluster and it is supposed to be an alternative scaffold protein [63]. Recently, it has been shown that the complex made by the two homologs, IscA1/IscA2, interacting with IBA57 and in the presence of ferredoxin, assembles a $[4 \mathrm{Fe}-4 \mathrm{~S}]^{2+}$ cluster by the reductive coupling of two $[2 \mathrm{Fe}-2 \mathrm{~S}]^{2+}$ clusters $[64,65]$. Isd11 is a protein present only in eukaryotes. It plays a role as the adaptor between Nfs1 and the scaffold proteins, to promote sulfur release [66,67]. Another ancillary protein selectively present in prokaryotes is YfhJ [68]

Frataxin interacts with the proteins involved in the Fe-S assembly machinery [69-72] through a surface spreading from the acidic ridge to the $\beta 4$-sheet, as identified by mutating some of the residues belonging to these regions (E108, E111, D124 and W155, N146) [73]. Initially, frataxin was supposed to contribute to the Fe-S cluster formation as an iron donor $[74,75]$. Independent evidence shows that frataxin could act as a regulator of the reaction speed with an effect that is iron-dependent, by tuning the quantity of clusters formed to match the apo-acceptor concentration [76]. Nonetheless, the role of frataxin is still controversial; although in vitro activity assays show that bacterial frataxin, named CyaY, inhibits the cluster formation in bacteria [77-79], frataxin activates the reaction in yeast and in the human protein system [80]. The interaction between frataxin, the desulfurase and the scaffold protein was revealed and extensively investigated $[69,71,78]$. In prokaryotes, YfhJ (also called IscX), along with frataxin, was suggested to be a regulator of the IscS activity depending on the iron concentration [81]. Intriguingly, in prokaryotes, CyaY competes with YfhJ and FdX for the same site on IscS, and the concentration of iron cations modulate the binding affinity to IscS $[78,82,83]$.

\section{Frataxin: Structure and Stability}

Human frataxin is a nuclear encoded protein of 210 amino acids. The sequence contains a 20-amino acid mitochondrial targeting signal and a spacer (Figure 1) that is removed from the mitochondrial matrix by a two-steps process, to produce mature frataxin [84].

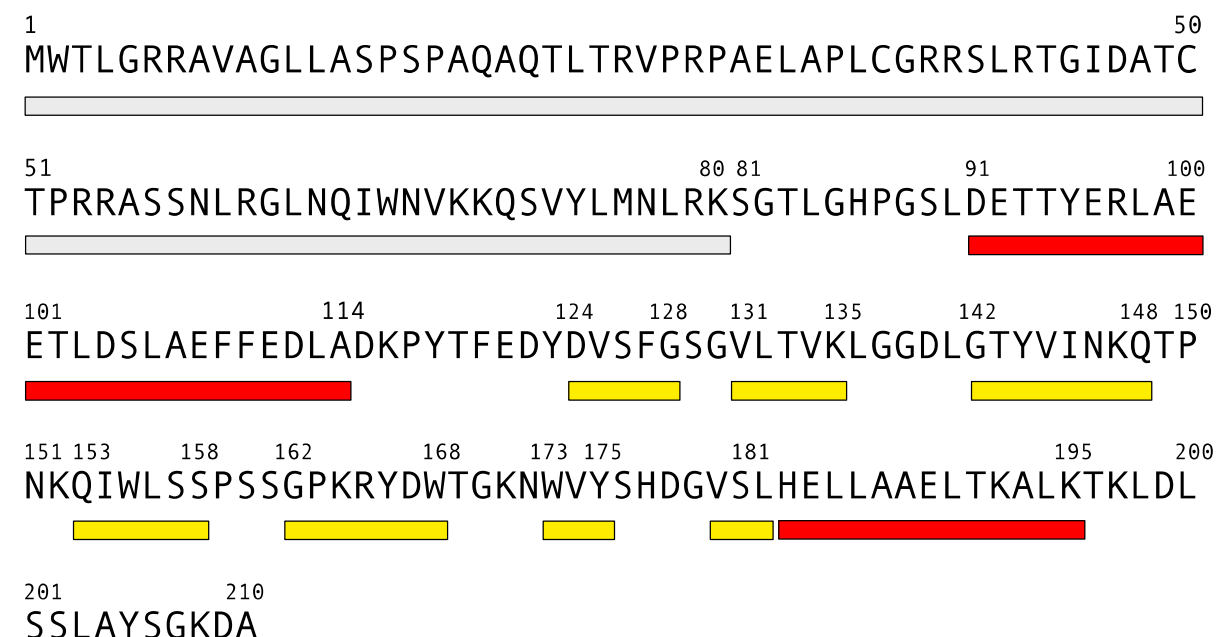

Figure 1. Human frataxin sequence and secondary structure, as reported for PDB 1EKG. Rectangles report the mitochondrial targeting signal and a spacer (gray), $\alpha$-helices (red) and $\beta$-strands (yellow). 
Several solutions and crystal structures have been deposited in PDB for the bacterial and eukaryotic orthologues of frataxin [85-92]. The structures of yeast and human and bacterial frataxin orthologs are similar and consist of two regions: a compact globular C-terminal domain [89] and an intrinsically unfolded N-terminal tail (residues 81-92 in human frataxin). Overall, the domain presents a planar $\alpha-\beta$ sandwich structure motif $(\alpha 1 \beta 1 \beta 2 \beta 3 \beta 4 \beta 5 \beta 6(\beta 7) \alpha 2)$ with two terminal $\alpha$-helices supported by a platform provided by five antiparallel $\beta$-strands and a sixth (and in human frataxin also a seventh) $\beta$-strand that intersects the planes (Figure 2, top).
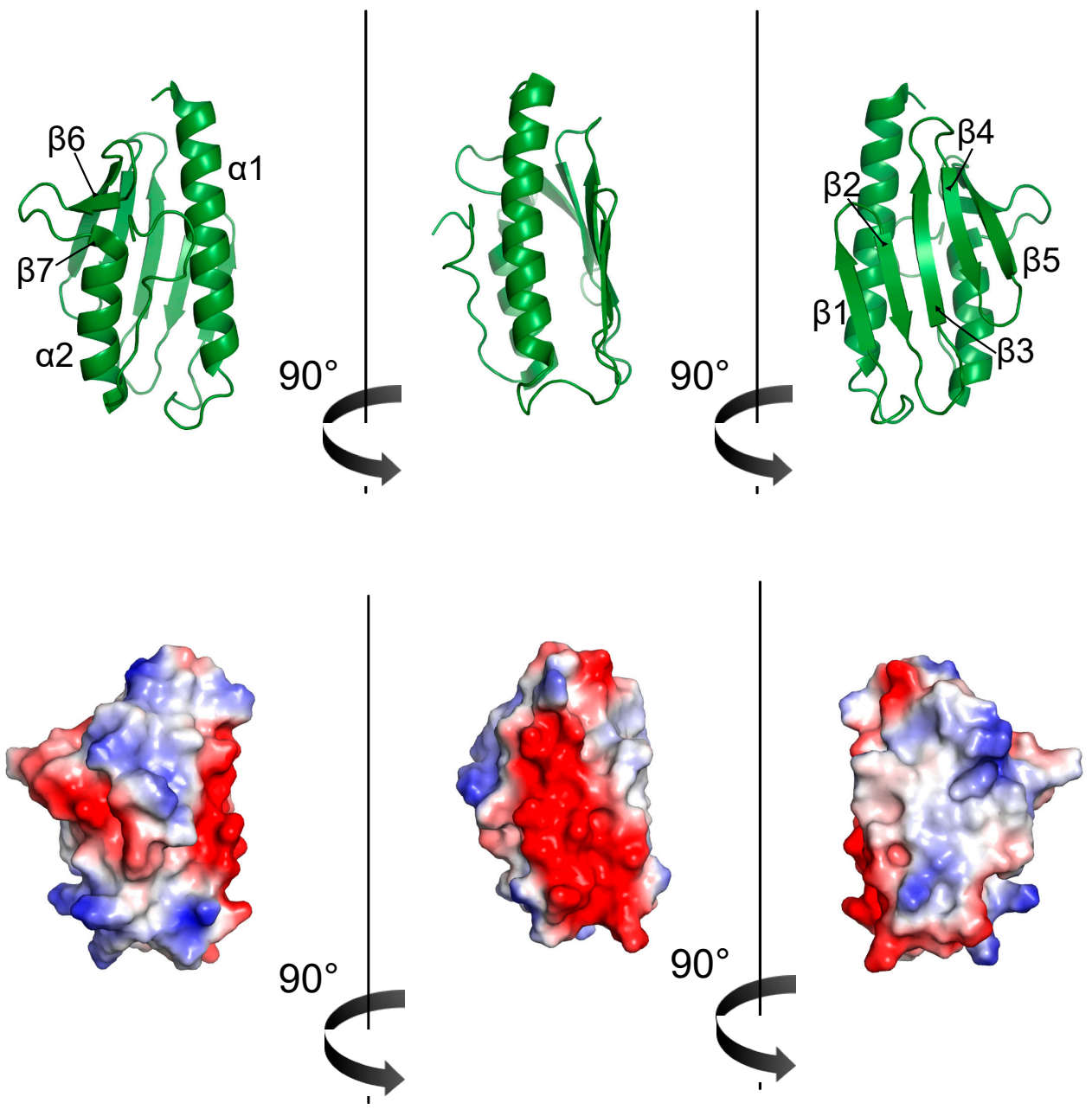

Figure 2. Human frataxin structure (PDB 1EKG) (top) and electrostatic surface (bottom).

Helices $\alpha 1$ and $\alpha 2$ are roughly parallel and secured by hydrophobic and aromatic residues (in human frataxin, L106, F110, and L113, and L186, L190 and L194, respectively). The spatial orientation is also stabilized by the interactions between hydrophobic amino acids on the $\beta$-sheet surface and additionally by the C-terminal tail (in human frataxin, T196, L198, and L200) [85,86,88-90]. As for human frataxin, the N-terminal tail of the yeast ortholog (Yfh1) is flexible and unfolded [6,93]. On the other hand, bacterial CyaY lacks any appreciable residues in the N-terminal, compared to $\alpha 1$ [7]. The three orthologues have a C-terminal tail with different lengths, without elements of a secondary structure $[7,94]$ and with a higher mobility compared to the rest of the molecule, as confirmed by the smaller than average $T_{1} / T_{2}$ and small or negative NOE values [95], in agreement with larger rmsd of the solution bundle in these regions [89]. 
The strong structural similarity between the three frataxin orthologs corresponds to the high degree of conservation in the amino acid sequence [5] (Figure 3).

CYAY ECOLI FRDA HUMAN FRDA_YEAST

CYAY_ECOLI FRDA HUMAN FRDA_YEAST

CYAY_ECOLI FRDA HUMAN FRDA_YEAST

CYAY_ECOLI FRDA HUMAN FRDA_YEAST
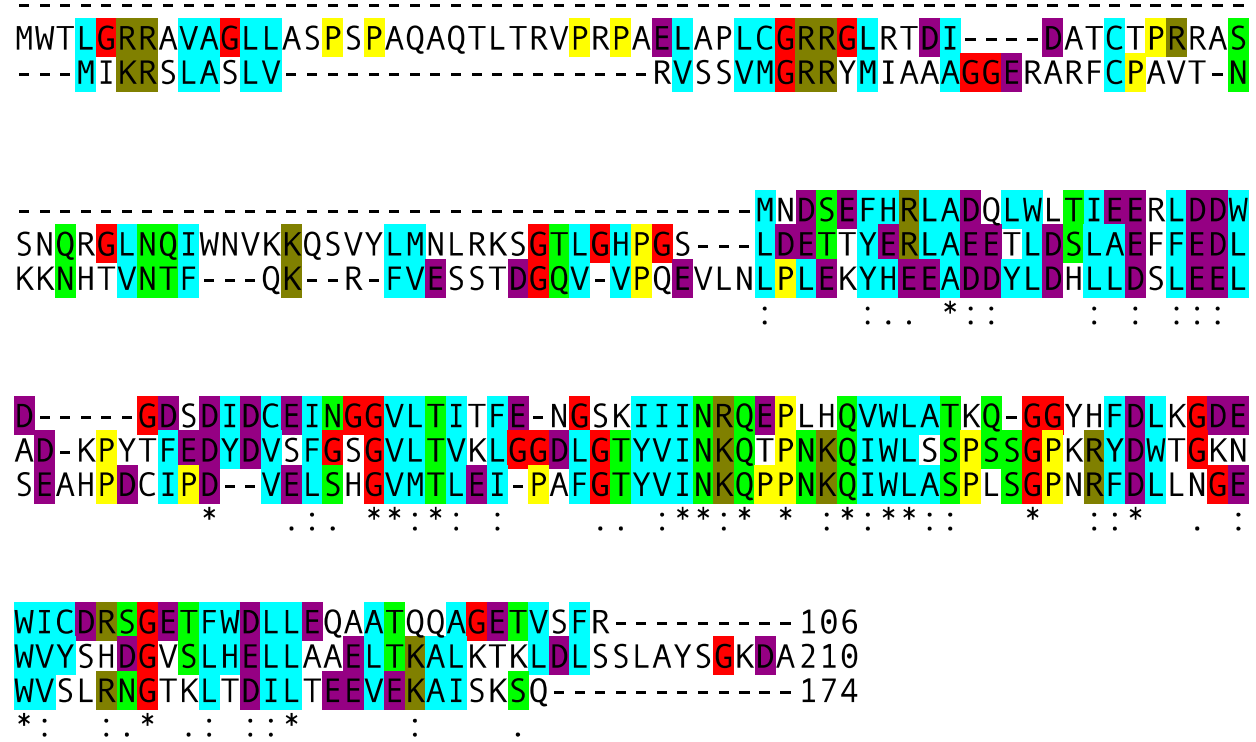

Figure 3. Multiple alignment of the three frataxin orthologues obtained with Clustal Omega and color-coded to emphasize the conserved sequence.

Mature human frataxin shares $36 \%$ of identical amino acids with yeast Yfh1 and $20 \%$ with bacterial CyaY. Two protein surfaces that are conserved throughout evolution were identified. An exposed surface, named as the "acidic ridge" and located in the $\alpha 1$ and $\beta 1$ regions, is constituted by conserved negatively charged residues (E92, E96, E100, E101, D104, E108, E111, D112 and D115 in human frataxin), and is responsible for iron binding [89] (Figure 2, bottom). The other conserved surface forms an extended patch involving the positively charged and apolar residues from the beta-sheet [9]. The mutations that commonly result in FRDA are in these surfaces.

Despite the high degree of sequence homology and fold, the three frataxins have different stabilities in solution. While the bacterial and human orthologs have melting points at around $54{ }^{\circ} \mathrm{C}$ and $60{ }^{\circ} \mathrm{C}$, respectively [94], yeast Yfh1 is less stable, with a melting point at around $35^{\circ} \mathrm{C}$ and a temperature of cold denaturation above zero degrees $\left(7^{\circ} \mathrm{C}\right)$ [20-22]. Yfh1 is one of the few proteins whose cold denaturation is observable above water, freezing at nearly physiological conditions. The presence of salt and iron generally increases the stability, whereas the nature of the buffer has a minimal effect. Owing to the possibility of observing both unfolding transitions without the addition of denaturants, Yfh1 has extensively been used to investigate the mechanisms at the base of heat and cold denaturation [24,96-98]. The length of the C-terminal tail (longer in humans, intermediate in CyaY and shorter in Yfh1) influences the general stability of frataxin by insertion into the grove between $\alpha 1$ and $\alpha 2$ and providing additional contacts that help to stabilize the fold $[16,94]$.

\section{Frataxin Missense Mutation}

The majority of the FRDA patients are compounds homozygous for (GAA)n expansion. Another small but significant number (2-8\%) is observed to be heterozygous, with a (GAA)n expansion on one allele and a point mutation on the other $[99,100]$. To date, single base pair deletions, insertions and substitutions have been reported, counting at least 44 point mutations reported in the literature [101]. A list of the most common mutants is presented in Table 1. 
Table 1. List of deletions, insertions and substitutions in the coding sections of the frataxin gene responsible for the FRDA known, to date (more comprehensive tables can be found in Pook, 2000 [102] and Gellera, 2007 [99]).

\begin{tabular}{|c|c|c|c|}
\hline Location & Nucleotide Change & Mutation & Effect \\
\hline \multirow[t]{5}{*}{ Exon 1} & $\mathrm{~A} \rightarrow \mathrm{C}$ at 1 & $1 \mathrm{~A} \rightarrow \mathrm{C}$ & Incorrect initiation \\
\hline & $\mathrm{T} \rightarrow \mathrm{C}$ at 2 & $2 \mathrm{~T} \rightarrow \mathrm{C}$ & Incorrect initiation \\
\hline & $\mathrm{G} \rightarrow \mathrm{T}$ at 3 & $3 \mathrm{G} \rightarrow \mathrm{T}$ & Incorrect initiation \\
\hline & Deletion of $C$ at 157 & 157delC & Frameshift \\
\hline & Insertion of $C$ after 157 & 157insC & Frameshift \\
\hline Exon 2 & GTCA $\rightarrow$ TTG at 202-205 & 202GTCA $\rightarrow$ TTG & Frameshift \\
\hline \multirow[t]{5}{*}{ Exon 3} & $\mathrm{~T} \rightarrow \mathrm{G}$ at 317 & L106X & Nonsense \\
\hline & $\mathrm{T} \rightarrow \mathrm{C}$ at 317 & L106S & Missense \\
\hline & Deletion of $\mathrm{T}$ at 317 & 317delT & Frameshift \\
\hline & $\begin{array}{c}\text { Deletion of 13bp between } \\
340 \text { and } 352\end{array}$ & 340del13 & Frameshift \\
\hline & $\mathrm{G} \rightarrow \mathrm{T}$ at 364 & D122Y & Missense \\
\hline \multirow[t]{6}{*}{ Exon 4} & $\mathrm{G} \rightarrow \mathrm{T}$ at 389 & G130V & Missense \\
\hline & $\mathrm{G} \rightarrow \mathrm{T}$ at 410 & G137V & Missense \\
\hline & $\mathrm{C} \rightarrow \mathrm{G}$ at 438 & N146K & Missense \\
\hline & $\mathrm{A} \rightarrow \mathrm{T}$ at 460 & $\mathrm{I} 154 \mathrm{~F}$ & Missense \\
\hline & $\mathrm{T} \rightarrow \mathrm{C}$ at 464 & W155R & Missense \\
\hline & $\mathrm{T} \rightarrow \mathrm{C}$ at 467 & L156P & Missense \\
\hline \multirow[t]{6}{*}{ Exon $5 a$} & $\mathrm{C} \rightarrow \mathrm{T}$ at 493 & R165C & Missense \\
\hline & $\mathrm{T} \rightarrow \mathrm{G}$ at 517 & W173G & Missense \\
\hline & $\mathrm{C} \rightarrow \mathrm{T}$ at 544 & L182F & Missense \\
\hline & $\mathrm{T} \rightarrow \mathrm{A}$ at 545 & L182H & Missense \\
\hline & $\mathrm{A} \rightarrow \mathrm{G}$ at 548 & H183R & Missense \\
\hline & $\mathrm{T} \rightarrow \mathrm{G}$ at 593 & L198R & Missense \\
\hline
\end{tabular}

FRDA patients homozygous for (GAA)n expansion usually present altered protein levels. The clinical presentation of the heterozygous patients can be either classical or with atypical or milder phenotypes, as missense mutations usually alter the features needed for the biological function or stability depending on the residues. The conserved amino acids of the hydrophobic core are usually essential for the folding; on the contrary, conserved exposed ones are usually involved in its function. In Table 2, we summarize the effects of the mutations on the frataxin structure and function and the disease phenotype in heterozygous patients carrying the most common point mutations identified to date in FRDA patients (Figure 4).

Table 2. Summary of frataxin point mutations in FRDA: the location and effect on the protein structure, temperatures of unfolding (as a reference, $\mathrm{T}_{\mathrm{m}}$ of the frataxin wild-type is $60^{\circ} \mathrm{C}$, as reported by Adinolfi, 2004 [94]), protein interaction site and FRDA phenotype.

\begin{tabular}{|c|c|c|c|c|c|c|}
\hline Mutation & Location & Structural Effects & Other Effects & $\operatorname{Tm}\left({ }^{\circ} \mathrm{C}\right)$ & $\begin{array}{c}\text { Affected } \\
\text { Protein } \\
\text { Interaction }\end{array}$ & Phenotype \\
\hline L106S & $\alpha 1$ & $\begin{array}{l}\text { Steric strain due to } \\
\text { replacement of a apolar } \\
\text { residue with a smaller } \\
\text { polar one. }\end{array}$ & & & & $\begin{array}{c}\text { milder } \\
\text { symptoms }\end{array}$ \\
\hline D122Y & loop & $\begin{array}{c}\text { Change of a conserved } \\
\text { negatively charged residue. }\end{array}$ & $\begin{array}{l}\text { Lower iron } \\
\text { binding } \\
\text { stoichiometry. }\end{array}$ & $\begin{array}{l}50.4^{\circ} \mathrm{C} \\
\text { (Correia, } \\
2008)\end{array}$ & IscS & $\begin{array}{l}\text { mild and } \\
\text { atypical } \\
\text { disease }\end{array}$ \\
\hline
\end{tabular}


Table 2. Cont.

\begin{tabular}{|c|c|c|c|c|c|c|}
\hline Mutation & Location & Structural Effects & Other Effects & $\operatorname{Tm}\left({ }^{\circ} \mathrm{C}\right)$ & $\begin{array}{c}\text { Affected } \\
\text { Protein } \\
\text { Interaction }\end{array}$ & Phenotype \\
\hline G130V & turn $\beta 1-\beta 2$ & $\begin{array}{l}\text { Steric strain due to } \\
\text { replacement of a glycine that } \\
\text { is in a conformation not } \\
\text { allowed to other residues. }\end{array}$ & $\begin{array}{l}\text { Higher } \\
\text { degradation of } \\
\text { frataxin in the } \\
\text { cell. Lower iron } \\
\text { affinity. }\end{array}$ & $\begin{array}{l}43.2^{\circ} \mathrm{C} \\
\text { (Correia, } \\
2008)\end{array}$ & & $\begin{array}{l}\text { mild and } \\
\text { atypical } \\
\text { disease }\end{array}$ \\
\hline G137V & turn $\beta 1-\beta 2$ & $\begin{array}{l}\text { Steric strain due to } \\
\text { replacement of a glycine that } \\
\text { is in a conformation not } \\
\text { allowed to other residues } \\
\text { and steric hindrance. }\end{array}$ & $\begin{array}{l}\text { Lower } \\
\text { efficiency of the } \\
\text { folding process. }\end{array}$ & $\begin{array}{l}46^{\circ} \mathrm{C} \\
\text { (Faggianelli, } \\
\text { 2015) }\end{array}$ & & $\begin{array}{l}\text { milder } \\
\text { symptoms }\end{array}$ \\
\hline N146K & $\beta 3$ & Electrostatic strain. & & $\begin{array}{c}69.4^{\circ} \mathrm{C} \\
(\text { Castro, 2019) }\end{array}$ & IscU & classical \\
\hline $\mathrm{I} 154 \mathrm{~F}$ & $\beta 4$ & $\begin{array}{c}\text { Steric strain due to } \\
\text { replacement of a } \\
\text { hydrophobic residue by a } \\
\text { larger one. }\end{array}$ & $\begin{array}{c}\text { Maturation } \\
\text { with increase of } \\
\text { insoluble } \\
\text { intermidiates. }\end{array}$ & $\begin{array}{l}50.7^{\circ} \mathrm{C} \\
\text { (Correia, } \\
2008)\end{array}$ & Isd11 & classical \\
\hline W155R & $\beta 4$ & $\begin{array}{c}\text { Replacement of a bulky } \\
\text { highly conserved aromatic } \\
\text { residue with a positively } \\
\text { charged one. }\end{array}$ & & $\begin{array}{l}61.4^{\circ} \mathrm{C} \\
\text { (Correia, } \\
2008)\end{array}$ & $\begin{array}{l}\text { Isd11/Nfs1 } \\
\text { and IscU }\end{array}$ & classical \\
\hline L156P & $\beta 4$ & $\begin{array}{l}\text { Disruption in the } \beta \text {-sheet by } \\
\text { introducing a proline. }\end{array}$ & & & IscU & classical \\
\hline R165C & $\beta 5$ & $\begin{array}{l}\text { Replacement of a conserved } \\
\text { positively charged residue } \\
\text { with a cysteine that is } \\
\text { hydrophobic and might } \\
\text { form intermolecular } \\
\text { disulfide bond. }\end{array}$ & & & IscU & $\begin{array}{l}\text { mild and } \\
\text { atypical } \\
\text { disease }\end{array}$ \\
\hline W173G & $\beta 6$ & $\begin{array}{l}\text { The introduction of a glycine } \\
\text { affects the protein folding. }\end{array}$ & $\begin{array}{c}\text { Poorly } \\
\text { expressed. }\end{array}$ & & & classical \\
\hline L182F & $\alpha 2$ & $\begin{array}{c}\text { replacement of a } \\
\text { hydrophobic residue by a } \\
\text { larger one. }\end{array}$ & $\begin{array}{c}\text { Prone to } \\
\text { degradation. }\end{array}$ & & & $\begin{array}{l}\text { mild and } \\
\text { atypical } \\
\text { disease }\end{array}$ \\
\hline L182H & $\alpha 2$ & $\begin{array}{l}\text { Electrostatic strain due to } \\
\text { replacement of a } \\
\text { hydrophobic residue with a } \\
\text { hydrophilic one. }\end{array}$ & $\begin{array}{c}\text { Prone to } \\
\text { degradation. }\end{array}$ & & & classical \\
\hline H183R & $\alpha 2$ & $\begin{array}{l}\text { Strain due to replacement of } \\
\text { a residue with a bulkier one. }\end{array}$ & & & & classical \\
\hline L198R & $\begin{array}{l}\text { C-terminal } \\
\text { region }(\mathrm{CTR})\end{array}$ & $\begin{array}{l}\text { Electrostatic strain and } \\
\text { disruption of the interaction } \\
\text { of CTR with } \alpha 1 \text { and } \alpha 2 \text {. }\end{array}$ & $\begin{array}{l}\text { Lower iron } \\
\text { binding affinity. }\end{array}$ & $\begin{array}{l}54.1^{\circ} \mathrm{C}(\text { Faraj } \\
2014)\end{array}$ & & classical \\
\hline
\end{tabular}

The mutations of the buried residues (L106, L182, H183 and L186) most likely disrupt the frataxin's fold and cause FRDA disease.

This is the case for the replacement of a $T$ with a $C$ at position 317 in exon 3, which resulted in L106S missense. The patient carrying this mutation presented milder symptoms, such as the slow rate of disease progression, only lower limb weakness and no cardiac abnormalities or diabetes [103]. L106 belongs to the $\alpha 1$ helix and is conserved throughout the species. This is a nonconservative substitution of an apolar amino acid with a smaller polar residue with a lower tendency to form a helix [103]. The mutation from $\mathrm{T}$ to $\mathrm{G}$ was also reported. It causes the change from L106 to a stop codon (L106X) and leads to a truncated form of frataxin [102]. Patients carrying this mutation show a total deficiency of frataxin and typical FRDA with a severe course of the disease [32]. 


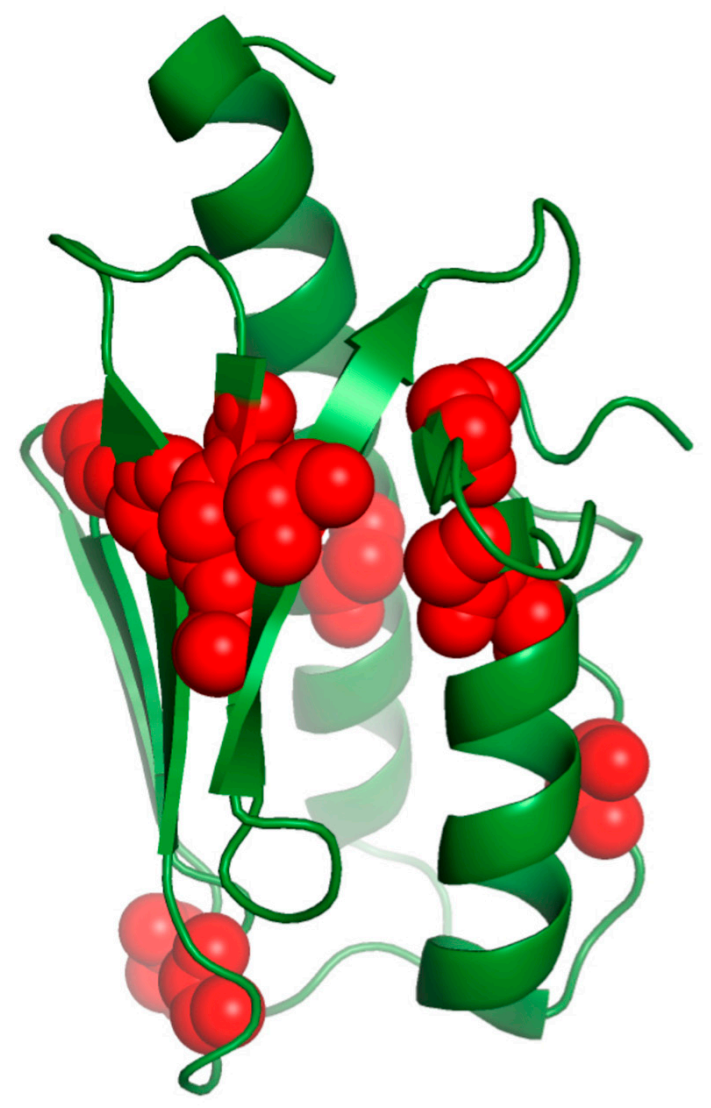

Figure 4. Frataxin residues substituted in FRDA mutants are colored in red.

In other cases, individuals carry a $\mathrm{C}$ to $\mathrm{T}$ substitution altering the codon at position 182 and present a leucine replaced by the larger phenylalanine (L182F) in the $\alpha 2$ helix. They show atypical and mild symptoms, such as minimal dysarthria, little upper limb disfunction, absent ankle jerks, but reduced knee reflexes and progressively worsening lower limb ataxia [104]. Although L182 is supposed to be essential for the frataxin function, as it is a conserved residue, the L182F variant is still able to bind and activate the Fe-S machinery. On the other hand, the L182H mutation shows an alteration in the circular dichroism spectrum, suggesting a change in the secondary structure because of the substitution of a hydrophobic residue with a charged one.

$\mathrm{H} 183$ is a buried residue responsible for human frataxin stabilization, as it acts as a lock between the $\alpha 1$ and $\alpha 2$ helices, despite it is a non-conserved residue. Patients with H183R have been reported [100]. Although this is a conservative replacement, in which a positively charged amino acid is replaced by another one with similar characteristics, the steric difference between the two residues probably causes a strain disrupting the interaction.

Furthermore, the alteration in frataxin's structure would arise from the mutation of $\beta$-sheet conserved residues with side chains directed towards the hydrophobic core, such as for L156 and W173.

L156 is highly conserved during evolution and a replacement by a proline (L156P) has been reported [100]. This is likely to profoundly affect the tridimensional structure, as proline has a high conformational rigidity and acts as a disruptor of the secondary structure. Consequently, the binding with IscU is affected [101]. W173 is also highly conserved and its replacement by a smaller residue, such as a glycine (W173G), may deeply affect protein folding [100] to the point that, when trying to produce it, the mutated protein is poorly expressed in the mature form [105].

On the other hand, the mutations of conserved exposed residues on the $\beta$-sheet plane (I154, N146, W155 and R165) may alter the ability of frataxin to bind its partners and disrupt the function. 
Patients with an I154F mutation were found in a restricted area of southern Italy, probably because of the founder effect, in which the mutation is passed down from an individual to other generations. These patients present the typical FRDA phenotype [32,100]. The missense mutation affects a conserved residue located in $\beta 4$, a highly conserved region involved in the interaction with Isd11 [105]. The maturation of this pathological variant is affected and results in the presence of insoluble intermediates [106]. The I154F mutant presents reduced stability with a $\mathrm{T}_{\mathrm{m}}$ of $50.7{ }^{\circ} \mathrm{C}$ [95] and precipitates in the presence of iron $[95,107]$.

Among the conserved residues on the $\beta$-sheet plane, N146, W155 and R165 are significative as they are adjacent in the structure, and the mutation of one has a consequence on the other. Interestingly, the patients carrying the N146K mutation presented classical features of FRDA; despite this, the frataxin mutant showed a stabilized native conformation with a $\mathrm{T}_{\mathrm{m}}$ of $69.4^{\circ} \mathrm{C}$ [9]. It has been suggested that the proximity of W155 and the replacing lysine may imbalance the electrostatic properties of the frataxin surface and affect the binding capacity of frataxin for its protein partners [73]. The W155R mutation causes a classical FRDA phenotype as well. W155 belongs to $\beta 4$ and is an exposed residue responsible for the interaction with ISD11 that is disrupted after the mutation [105], as are the interactions with IscU and Nfs1 [73]. This mutant retains a native fold and has a slightly reduced stability [6,107] with a $\mathrm{T}_{\mathrm{m}}$ of $61.4{ }^{\circ} \mathrm{C}$ [95]. The destabilization is expected from the deletion of a $\pi$-cation interaction between W155 and contiguous R165, and the electrostatic repulsion resulting from the insertion of arginine. On the contrary, patients with a compound heterozygous for the R165C substitution have a milder disease course (no dysarthria, gait disturbance and ankle jerks) [104]. This mutation occurs in a conserved region of $\beta 5$. It is a nonconservative replacement, altering a basic amino acid to a hydrophobic non-charged one, which might also form an intermolecular disulfide bond and perturb the interaction with IscU [101].

As a result of their unique properties of backbone conformations, glycines are often positioned in loops and their substitution necessarily leads to the destabilization of the fold.

The G130V mutation is relatively common in FRDA [104]. People presenting frataxin with the G130V mutation have an atypical mild disease with an early onset, spastic gait, absence of dysarthria, retained tendon reflexes, mild or no ataxia and the slow progression of symptoms $[100,104,108]$. This suggests that, although the residue is highly conserved, the mutation only partially influences the frataxin function. G130V results in a large change in the $T_{m}$ value $\left(43.2^{\circ} \mathrm{C}\right)$ [95] and it seems to affect the maturation of the protein [106]. G130 belongs to a turn between strands $\beta 1$ and $\beta 2$, and its backbone carbonyl oxygen forms a hydrogen bond with the amide of K147, which is involved in binding the scaffold protein IscU [101] and belongs to a ubiquitination site. The mutation of G130 thus results in a higher degradation of frataxin in the cell [109] and in the disruption of the interaction with IscU. In addition, the G130V mutation affects the frataxin iron affinity $[95,107]$.

An FRDA patient with a compound heterozygous with an G137V substitution was also reported. It described an onset at 25 years of age and phenotypes, such as gait and trunk ataxia, mild dysarthria, absent tendon reflexes in the upper and lower limbs and impaired position and vibratory sense in the lower limbs [110]. Frataxin carrying the G137V mutation presented no effects on the structure or activity of the protein, but had a reduced conformational stability with a melting temperature of $46^{\circ} \mathrm{C}$. This is supposed to affect the efficiency of the folding process causing reduced levels of the active protein [110]. G137 is not an evolutionary conserved residue and is located in the C-terminal globular domain at the end of the $\beta 2$ strand. Its mutation to a valine is supposed to have an important influence on the turn and, additionally, to cause steric hindrance with other residues. Interestingly, D122 packs against G137, suggesting that the two mutations have the same effect [110]. Similar to the patients carrying the G137V mutation, those found with the D122Y mutation had a mild and atypical disease [100]. D122 belongs to the N-terminus and its mutation does not affect the folding. However, by changing the polarity of the anionic surface, it 
reduces the protein stability [6] with a $\mathrm{T}_{\mathrm{m}}$ of $50.4^{\circ} \mathrm{C}$ [95]. The $\mathrm{D} 122 \mathrm{Y}$ variant has a lower iron binding stoichiometry [95] and a perturbed interaction with the desulfurase [101].

As it was already described above, the C-terminal tail plays a crucial role in the stabilization of the fold [16,94]. A compound heterozygous patient was reported to present a base substitution that converted leucine to arginine at amino acid position 198 (L198R), located in an apolar environment in the C-terminus. The patient showed a typical FRDA phenotype [111]. L198 is a conserved residue and the mutation causes an alteration in charge with a consequent destabilization of the protein, with a $\mathrm{T}_{\mathrm{m}}$ of $54.1{ }^{\circ} \mathrm{C}$ [112], due to the disruption of the interaction of the C-terminus with the $\alpha 1$ and $\alpha 2$ helices. L198R also showed a lower iron binding capability [112]. To determine the relevance of the frataxin Cterminus, other mutations at this position were also investigated (L198A and L198C). They all presented protein destabilization [113] as well as the absence of the C-terminus (residues 196-210) [94,112]. On the other hand, the truncation of frataxin at residue 193 determines FRDA with a rapid disease progression [114].

Such a variety of examples prove that similar dramatic or milder phenotypes do not necessarily derive from the same cause and, actually, may have a different origin at a molecular level. Depending on their localization in the structure, specific mutations can impair the function by disrupting the interaction with essential partners and decrease the protein stability leading to the degradation or disruption of the folding.

\section{Conclusions}

Thermal stability is of central importance in both science and medicine. The mechanisms by which protein heat resistance is modulated to allow the host organism to adapt to extreme environmental conditions is a topic of increasing interest in the research. Moreover, the investigation of protein stability has become more and more important, because protein misfolding and aggregation are key features of several neurodegenerative diseases, including Alzheimer's disease, Huntington's disease, Parkinson disease, cystic fibrosis and ALS [115]. In addition, several cancers are caused by the mutation and misfolding of proteins that are the key regulators of growth and differentiation [116].

In this study, we analyzed FRDA as an example of a disease that is caused by protein misfolding and a loss of protein function. Compound heterozygous patients with both point mutations and GAA expansion usually presented a severe FRDA phenotype, which resulted from reduced levels of functional frataxin. More attention to the mechanisms that lead to the misfunction of the frataxin gene, which affect frataxin maturation, folding, function or stability, will help in the future to establish a link between FRDA pathogenesis and phenotype, and inform treatment development.

Funding: We acknowledge financial support from UK Dementia Research Institute (RE1 3556), which is funded by the Medical Research Council, Alzheimer's Society and Alzheimer's Research UK.

Acknowledgments: I gratefully thank Annalisa Pastore and Pierandrea Temussi for their useful suggestions and writing assistance.

Conflicts of Interest: The author declares no conflict of interest.

\section{References}

1. Rodriguez, J.A.; Shaw, B.F.; Durazo, A.; Sohn, S.H.; Doucette, P.A.; Nersissian, A.M.; Faull, K.F.; Eggers, D.K.; Tiwari, A.; Hayward, L.J.; et al. Destabilization of apoprotein is insufficient to explain $\mathrm{Cu}, \mathrm{Zn}$-superoxide dismutase-linked ALS pathogenesis. Proc. Natl. Acad. Sci. USA 2005, 102, 10516-10521. [CrossRef] [PubMed]

2. Plaza del Pino, I.M.; Ibarra-Molero, B.; Sanchez-Ruiz, J.M. Lower kinetic limit to protein thermal stability: A proposal regarding protein stability in vivo and its relation with misfolding diseases. Proteins 2000, 40, 58-70. [CrossRef]

3. Bonaccorsi, M.; Knight, M.J.; Le Marchand, T.; Dannatt, H.R.W.; Schubeis, T.; Salmon, L.; Felli, I.C.; Emsley, L.; Pierattelli, R.; Pintacuda, G. Multimodal Response to Copper Binding in Superoxide Dismutase Dynamics. J. Am. Chem. Soc. 2020, 142, 19660-19667. [CrossRef]

4. Iannuzzi, C.; Adrover, M.; Puglisi, R.; Yan, R.; Temussi, P.A.; Pastore, A. The role of zinc in the stability of the marginally stable IscU scaffold protein. Protein Sci. 2014, 23, 1208-1219. [CrossRef] [PubMed] 
5. Pandolfo, M.; Pastore, A. The pathogenesis of Friedreich ataxia and the structure and function of frataxin. J. Neurol. 2009, 256 (Suppl. S1), 9-17. [CrossRef] [PubMed]

6. Pastore, A.; Puccio, H. Frataxin: A protein in search for a function. J. Neurochem. 2013, 126 (Suppl. S1), 43-52. [CrossRef]

7. Bencze, K.Z.; Kondapalli, K.C.; Cook, J.D.; McMahon, S.; Millan-Pacheco, C.; Pastor, N.; Stemmler, T.L. The structure and function of frataxin. Crit. Rev. Biochem. Mol. Biol. 2006, 41, 269-291. [CrossRef]

8. Muhlenhoff, U.; Lill, R. Biogenesis of iron-sulfur proteins in eukaryotes: A novel task of mitochondria that is inherited from bacteria. Biochim. Biophys. Acta 2000, 1459, 370-382. [CrossRef]

9. $\quad$ Castro, I.H.; Pignataro, M.F.; Sewell, K.E.; Espeche, L.D.; Herrera, M.G.; Noguera, M.E.; Dain, L.; Nadra, A.D.; Aran, M.; Smal, C.; et al. Frataxin Structure and Function. In Macromolecular Protein Complexes II: Structure and Function; Harris, J.R., Marles-Wright, J., Eds.; Springer, Cham: Cham, Switzerland, 2019; Volume 93, pp. 393-438. [CrossRef]

10. Privalov, P.L. Cold denaturation of proteins. Crit. Rev. Biochem. Mol. Biol. 1990, 25, 281-305. [CrossRef]

11. Becktel, W.J.; Schellman, J.A. Protein stability curves. Biopolymers 1987, 26, 1859-1877. [CrossRef]

12. Pucci, F.; Rooman, M. Physical and molecular bases of protein thermal stability and cold adaptation. Curr. Opin. Struct. Biol. 2017, 42, 117-128. [CrossRef] [PubMed]

13. Camilloni, C.; Bonetti, D.; Morrone, A.; Giri, R.; Dobson, C.M.; Brunori, M.; Gianni, S.; Vendruscolo, M. Towards a structural biology of the hydrophobic effect in protein folding. Sci. Rep. 2016, 6, 28285. [CrossRef] [PubMed]

14. Privalov, P.L.; Makhatadze, G.I. Contribution of hydration to protein folding thermodynamics. II. The entropy and Gibbs energy of hydration. J. Mol. Biol. 1993, 232, 660-679. [CrossRef] [PubMed]

15. van Dijk, E.; Hoogeveen, A.; Abeln, S. The hydrophobic temperature dependence of amino acids directly calculated from protein structures. PLoS Comput. Biol. 2015, 11, e1004277. [CrossRef] [PubMed]

16. Sanfelice, D.; Puglisi, R.; Martin, S.R.; Di Bari, L.; Pastore, A.; Temussi, P.A. Yeast frataxin is stabilized by low salt concentrations: Cold denaturation disentangles ionic strength effects from specific interactions. PLoS ONE 2014, 9, e95801. [CrossRef]

17. Lee, C.W.; Wang, H.J.; Hwang, J.K.; Tseng, C.P. Protein thermal stability enhancement by designing salt bridges: A combined computational and experimental study. PLoS ONE 2014, 9, e112751. [CrossRef]

18. Lanzarotti, E.; Biekofsky, R.R.; Estrin, D.A.; Marti, M.A.; Turjanski, A.G. Aromatic-aromatic interactions in proteins: Beyond the dimer. J. Chem. Inf. Model. 2011, 51, 1623-1633. [CrossRef]

19. Walden, H.; Bell, G.S.; Russell, R.J.; Siebers, B.; Hensel, R.; Taylor, G.L. Tiny TIM: A small, tetrameric, hyperthermostable triosephosphate isomerase. J. Mol. Biol. 2001, 306, 745-757. [CrossRef]

20. Alfano, C.; Sanfelice, D.; Martin, S.R.; Pastore, A.; Temussi, P.A. An optimized strategy to measure protein stability highlights differences between cold and hot unfolded states. Nat. Commun. 2017, 8, 15428. [CrossRef]

21. Puglisi, R.; Brylski, O.; Alfano, C.; Martin, S.R.; Pastore, A.; Temussi, P.A. Quantifying the thermodynamics of protein unfolding using 2D NMR spectroscopy. Commun. Chem. 2020, 3, 100. [CrossRef]

22. Pastore, A.; Martin, S.R.; Politou, A.; Kondapalli, K.C.; Stemmler, T.; Temussi, P.A. Unbiased cold denaturation: Low- and high-temperature unfolding of yeast frataxin under physiological conditions. J. Am. Chem. Soc. 2007, 129, 5374-5375. [CrossRef] [PubMed]

23. Szyperski, T.; Mills, J.L.; Perl, D.; Balbach, J. Combined NMR-observation of cold denaturation in supercooled water and heat denaturation enables accurate measurement of deltaC(p) of protein unfolding. Eur. Biophys. J. 2006, 35, 363-366. [CrossRef] [PubMed]

24. Puglisi, R.; Karunanithy, G.; Hansen, D.F.; Pastore, A.; Temussi, P.A. The anatomy of unfolding of Yfh1 is revealed by site-specific fold stability analysis measured by 2D NMR spectroscopy. Commun. Chem. 2021, 4, 127. [CrossRef]

25. Pucci, F.; Kwasigroch, J.M.; Rooman, M. SCooP: An accurate and fast predictor of protein stability curves as a function of temperature. Bioinformatics 2017, 33, 3415-3422. [CrossRef]

26. Pucci, F.; Bourgeas, R.; Rooman, M. Predicting protein thermal stability changes upon point mutations using statistical potentials: Introducing HoTMuSiC. Sci. Rep. 2016, 6, 23257. [CrossRef]

27. Tavernelli, I.; Cotesta, S.; Di Iorio, E.E. Protein dynamics, thermal stability, and free-energy landscapes: A molecular dynamics investigation. Biophys. J. 2003, 85, 2641-2649. [CrossRef]

28. Wu, L.C.; Lee, J.X.; Huang, H.D.; Liu, B.J.; Horng, J.T. An expert system to predict protein thermostability using decision tree. Expert Syst. Appl. 2009, 36, 9007-9014. [CrossRef]

29. Miotto, M.; Olimpieri, P.P.; Di Rienzo, L.; Ambrosetti, F.; Corsi, P.; Lepore, R.; Tartaglia, G.G.; Milanetti, E. Insights on protein thermal stability: A graph representation of molecular interactions. Bioinformatics 2019, 35, 2569-2577. [CrossRef]

30. Pastore, A.; Martin, S.R.; Temussi, P.A. Generalized View of Protein Folding: In Medio Stat Virtus. J. Am. Chem. Soc. 2019, 141, 2194-2200. [CrossRef]

31. Hartl, F.U. Protein Misfolding Diseases. Annu. Rev. Biochem. 2017, 86, 21-26. [CrossRef]

32. Campuzano, V.; Montermini, L.; Molto, M.D.; Pianese, L.; Cossee, M.; Cavalcanti, F.; Monros, E.; Rodius, F.; Duclos, F.; Monticelli, A.; et al. Friedreich's ataxia: Autosomal recessive disease caused by an intronic GAA triplet repeat expansion. Science 1996, 271, 1423-1427. [CrossRef] [PubMed]

33. Harding, A.E. Friedreich's ataxia: A clinical and genetic study of 90 families with an analysis of early diagnostic criteria and intrafamilial clustering of clinical features. Brain 1981, 104, 589-620. [CrossRef] [PubMed] 
34. Geoffroy, G.; Barbeau, A.; Breton, G.; Lemieux, B.; Aube, M.; Leger, C.; Bouchard, J.P. Clinical Description and Roentgenologic Evaluation of Patients with Friedreich's Ataxia. Can. J. Neurol. Sci. J. Can. Des Sci. Neurol. 1976, 3, 279-286. [CrossRef] [PubMed]

35. Durr, A.; Cossee, M.; Agid, Y.; Campuzano, V.; Mignard, C.; Penet, C.; Mandel, J.L.; Brice, A.; Koenig, M. Clinical and genetic abnormalities in patients with Friedreich's ataxia. N. Engl. J. Med. 1996, 335, 1169-1175. [CrossRef] [PubMed]

36. Finocchiaro, G.; Baio, G.; Micossi, P.; Pozza, G.; di Donato, S. Glucose metabolism alterations in Friedreich's ataxia. Neurology 1988, 38, 1292-1296. [CrossRef]

37. Chamberlain, S.; Shaw, J.; Wallis, J.; Rowland, A.; Chow, L.; Farrall, M.; Keats, B.; Richter, A.; Roy, M.; Melancon, S.; et al. Genetic homogeneity at the Friedreich ataxia locus on chromosome 9. Am. J. Hum. Genet. 1989, 44, 518-521.

38. Priller, J.; Scherzer, C.R.; Faber, P.W.; MacDonald, M.E.; Young, A.B. Frataxin gene of Friedreich's ataxia is targeted to mitochondria. Ann. Neurol. 1997, 42, 265-269. [CrossRef]

39. Koutnikova, H.; Campuzano, V.; Foury, F.; Dolle, P.; Cazzalini, O.; Koenig, M. Studies of human, mouse and yeast homologues indicate a mitochondrial function for frataxin. Nat. Genet. 1997, 16, 345-351. [CrossRef]

40. Campuzano, V.; Montermini, L.; Lutz, Y.; Cova, L.; Hindelang, C.; Jiralerspong, S.; Trottier, Y.; Kish, S.J.; Faucheux, B.; Trouillas, P.; et al. Frataxin is reduced in Friedreich ataxia patients and is associated with mitochondrial membranes. Hum. Mol. Genet. 1997, 6, 1771-1780. [CrossRef]

41. Montermini, L.; Richter, A.; Morgan, K.; Justice, C.M.; Julien, D.; Castellotti, B.; Mercier, J.; Poirier, J.; Capozzoli, F.; Bouchard, J.P.; et al. Phenotypic variability in Friedreich ataxia: Role of the associated GAA triplet repeat expansion. Ann. Neurol. 1997, 41, 675-682. [CrossRef]

42. Foury, F.; Cazzalini, O. Deletion of the yeast homologue of the human gene associated with Friedreich's ataxia elicits iron accumulation in mitochondria. FEBS Lett. 1997, 411,373-377. [CrossRef]

43. Babcock, M.; de Silva, D.; Oaks, R.; Davis-Kaplan, S.; Jiralerspong, S.; Montermini, L.; Pandolfo, M.; Kaplan, J. Regulation of mitochondrial iron accumulation by Yfh1p, a putative homolog of frataxin. Science 1997, 276, 1709-1712. [CrossRef] [PubMed]

44. Delatycki, M.B.; Williamson, R.; Forrest, S.M. Friedreich ataxia: An overview. J. Med. Genet. 2000, 37, 1-8. [CrossRef] [PubMed]

45. Stehling, O.; Elsasser, H.P.; Bruckel, B.; Muhlenhoff, U.; Lill, R. Iron-sulfur protein maturation in human cells: Evidence for a function of frataxin. Hum. Mol. Genet. 2004, 13, 3007-3015. [CrossRef] [PubMed]

46. Rotig, A.; de Lonlay, P.; Chretien, D.; Foury, F.; Koenig, M.; Sidi, D.; Munnich, A.; Rustin, P. Aconitase and mitochondrial iron-sulphur protein deficiency in Friedreich ataxia. Nat. Genet. 1997, 17, 215-217. [CrossRef]

47. Petrosino, M.; Pasquo, A.; Novak, L.; Toto, A.; Gianni, S.; Mantuano, E.; Veneziano, L.; Minicozzi, V.; Pastore, A.; Puglisi, R.; et al Characterization of human frataxin missense variants in cancer tissues. Hum. Mutat. 2019, 40, 1400-1413. [CrossRef]

48. Fuss, J.O.; Tsai, C.L.; Ishida, J.P.; Tainer, J.A. Emerging critical roles of Fe-S clusters in DNA replication and repair. Biochim. Biophys. Acta 2015, 1853, 1253-1271. [CrossRef]

49. Chen, O.S.; Crisp, R.J.; Valachovic, M.; Bard, M.; Winge, D.R.; Kaplan, J. Transcription of the yeast iron regulon does not respond directly to iron but rather to iron-sulfur cluster biosynthesis. J. Biol. Chem. 2004, 279, 29513-29518. [CrossRef]

50. Johnson, D.C.; Dean, D.R.; Smith, A.D.; Johnson, M.K. Structure, function, and formation of biological iron-sulfur clusters. Annu Rev. Biochem. 2005, 74, 247-281. [CrossRef]

51. Beinert, H.; Holm, R.H.; Munck, E. Iron-sulfur clusters: Nature's modular, multipurpose structures. Science 1997, 277, 653-659. [CrossRef]

52. Frazzon, J.; Fick, J.R.; Dean, D.R. Biosynthesis of iron-sulphur clusters is a complex and highly conserved process. Biochem. Soc. Trans. 2002, 30, 680-685. [CrossRef] [PubMed]

53. Rees, D.C.; Howard, J.B. Nitrogenase: Standing at the crossroads. Curr. Opin. Chem. Biol. 2000, 4, 559-566. [CrossRef]

54. Kispal, G.; Csere, P.; Prohl, C.; Lill, R. The mitochondrial proteins Atm1p and Nfs1p are essential for biogenesis of cytosolic Fe/S proteins. EMBO J. 1999, 18, 3981-3989. [CrossRef] [PubMed]

55. Zheng, L.; Cash, V.L.; Flint, D.H.; Dean, D.R. Assembly of iron-sulfur clusters. Identification of an iscSUA-hscBA-fdx gene cluster from Azotobacter vinelandii. J. Biol. Chem. 1998, 273, 13264-13272. [CrossRef]

56. Takahashi, Y.; Tokumoto, U. A third bacterial system for the assembly of iron-sulfur clusters with homologs in archaea and plastids. J. Biol. Chem. 2002, 277, 28380-28383. [CrossRef]

57. Lill, R.; Muhlenhoff, U. Iron-sulfur-protein biogenesis in eukaryotes. Trends Biochem. Sci. 2005, 30, 133-141. [CrossRef]

58. Mansy, S.S.; Cowan, J.A. Iron-sulfur cluster biosynthesis: Toward an understanding of cellular machinery and molecular mechanism. Acc. Chem. Res. 2004, 37, 719-725. [CrossRef]

59. Urbina, H.D.; Silberg, J.J.; Hoff, K.G.; Vickery, L.E. Transfer of sulfur from IscS to IscU during Fe/S cluster assembly. J. Biol. Chem. 2001, 276, 44521-44526. [CrossRef]

60. Huynen, M.A.; Snel, B.; Bork, P.; Gibson, T.J. The phylogenetic distribution of frataxin indicates a role in iron-sulfur cluster protein assembly. Hum. Mol. Genet. 2001, 10, 2463-2468. [CrossRef]

61. Puglisi, R.; Pastore, A. The role of chaperones in iron-sulfur cluster biogenesis. FEBS Lett. 2018, 592, 4011-4019. [CrossRef]

62. Puglisi, R.; Yan, R.; Adinolfi, S.; Pastore, A. A New Tessera into the Interactome of the isc Operon: A Novel Interaction between HscB and IscS. Front. Mol. Biosci. 2016, 3, 48. [CrossRef] [PubMed]

63. Krebs, C.; Agar, J.N.; Smith, A.D.; Frazzon, J.; Dean, D.R.; Huynh, B.H.; Johnson, M.K. IscA, an alternate scaffold for Fe-S cluster biosynthesis. Biochemistry 2001, 40, 14069-14080. [CrossRef] [PubMed] 
64. Weiler, B.D.; Bruck, M.C.; Kothe, I.; Bill, E.; Lill, R.; Muhlenhoff, U. Mitochondrial [4Fe-4S] protein assembly involves reductive [2Fe-2S] cluster fusion on ISCA1-ISCA2 by electron flow from ferredoxin FDX2. Proc. Natl. Acad. Sci. USA 2020, 117, 20555-20565. [CrossRef] [PubMed]

65. Brancaccio, D.; Gallo, A.; Piccioli, M.; Novellino, E.; Ciofi-Baffoni, S.; Banci, L. [4Fe-4S] Cluster Assembly in Mitochondria and Its Impairment by Copper. J. Am. Chem. Soc. 2017, 139, 719-730. [CrossRef]

66. Adam, A.C.; Bornhovd, C.; Prokisch, H.; Neupert, W.; Hell, K. The Nfs1 interacting protein Isd11 has an essential role in Fe/S cluster biogenesis in mitochondria. EMBO J. 2006, 25, 174-183. [CrossRef]

67. Wiedemann, N.; Urzica, E.; Guiard, B.; Muller, H.; Lohaus, C.; Meyer, H.E.; Ryan, M.T.; Meisinger, C.; Muhlenhoff, U.; Lill, R.; et al. Essential role of Isd11 in mitochondrial iron-sulfur cluster synthesis on Isu scaffold proteins. EMBO J. 2006, 25, 184-195. [CrossRef]

68. Pastore, C.; Adinolfi, S.; Huynen, M.A.; Rybin, V.; Martin, S.; Mayer, M.; Bukau, B.; Pastore, A. YfhJ, a molecular adaptor in iron-sulfur cluster formation or a frataxin-like protein? Structure 2006, 14, 857-867. [CrossRef]

69. Gerber, J.; Muhlenhoff, U.; Lill, R. An interaction between frataxin and Isu1/Nfs1 that is crucial for Fe/S cluster synthesis on Isu1. EMBO Rep. 2003, 4, 906-911. [CrossRef]

70. Muhlenhoff, U.; Gerber, J.; Richhardt, N.; Lill, R. Components involved in assembly and dislocation of iron-sulfur clusters on the scaffold protein Isu1p. EMBO J. 2003, 22, 4815-4825. [CrossRef]

71. Ramazzotti, A.; Vanmansart, V.; Foury, F. Mitochondrial functional interactions between frataxin and Isu1p, the iron-sulfur cluster scaffold protein, in Saccharomyces cerevisiae. FEBS Lett. 2004, 557, 215-220. [CrossRef]

72. Puglisi, R.; Boeri Erba, E.; Pastore, A. A Guide to Native Mass Spectrometry to determine complex interactomes of molecular machines. FEBS J. 2020, 287, 2428-2439. [CrossRef] [PubMed]

73. Schmucker, S.; Martelli, A.; Colin, F.; Page, A.; Wattenhofer-Donze, M.; Reutenauer, L.; Puccio, H. Mammalian frataxin: An essential function for cellular viability through an interaction with a preformed ISCU/NFS1/ISD11 iron-sulfur assembly complex. PLoS ONE 2011, 6, e16199. [CrossRef] [PubMed]

74. Yoon, T.; Cowan, J.A. Iron-sulfur cluster biosynthesis. Characterization of frataxin as an iron donor for assembly of [2Fe-2S] clusters in ISU-type proteins. J. Am. Chem. Soc. 2003, 125, 6078-6084. [CrossRef] [PubMed]

75. Layer, G.; Ollagnier-de Choudens, S.; Sanakis, Y.; Fontecave, M. Iron-sulfur cluster biosynthesis: Characterization of Escherichia coli CYaY as an iron donor for the assembly of [2Fe-2S] clusters in the scaffold IscU. J. Biol. Chem. 2006, 281, 16256-16263. [CrossRef] [PubMed]

76. Adinolfi, S.; Iannuzzi, C.; Prischi, F.; Pastore, C.; Iametti, S.; Martin, S.R.; Bonomi, F.; Pastore, A. Bacterial frataxin CyaY is the gatekeeper of iron-sulfur cluster formation catalyzed by IscS. Nat. Struct. Mol. Biol. 2009, 16, 390-396. [CrossRef] [PubMed]

77. Foury, F.; Pastore, A.; Trincal, M. Acidic residues of yeast frataxin have an essential role in Fe-S cluster assembly. EMBO Rep. 2007, 8, 194-199. [CrossRef]

78. Prischi, F.; Konarev, P.V.; Iannuzzi, C.; Pastore, C.; Adinolfi, S.; Martin, S.R.; Svergun, D.I.; Pastore, A. Structural bases for the interaction of frataxin with the central components of iron-sulphur cluster assembly. Nat. Commun. 2010, 1, 95. [CrossRef]

79. Marengo, M.; Puglisi, R.; Oliaro-Bosso, S.; Pastore, A.; Adinolfi, S. Enzymatic and Chemical In Vitro Reconstitution of Iron-Sulfur Cluster Proteins. Methods Mol. Biol. 2021, 2353, 79-95. [CrossRef]

80. Tsai, C.L.; Barondeau, D.P. Human frataxin is an allosteric switch that activates the Fe-S cluster biosynthetic complex. Biochemistry 2010, 49, 9132-9139. [CrossRef]

81. Adinolfi, S.; Puglisi, R.; Crack, J.C.; Iannuzzi, C.; Dal Piaz, F.; Konarev, P.V.; Svergun, D.I.; Martin, S.; Le Brun, N.E.; Pastore, A The Molecular Bases of the Dual Regulation of Bacterial Iron Sulfur Cluster Biogenesis by CyaY and IscX. Front. Mol. Biosci. 2017, 4, 97. [CrossRef]

82. Kim, J.H.; Bothe, J.R.; Frederick, R.O.; Holder, J.C.; Markley, J.L. Role of IscX in iron-sulfur cluster biogenesis in Escherichia coli. J. Am. Chem. Soc. 2014, 136, 7933-7942. [CrossRef] [PubMed]

83. Yan, R.; Konarev, P.V.; Iannuzzi, C.; Adinolfi, S.; Roche, B.; Kelly, G.; Simon, L.; Martin, S.R.; Py, B.; Barras, F.; et al. Ferredoxin competes with bacterial frataxin in binding to the desulfurase IscS. J. Biol. Chem. 2013, 288, 24777-24787. [CrossRef] [PubMed]

84. Gordon, D.M.; Kogan, M.; Knight, S.A.; Dancis, A.; Pain, D. Distinct roles for two N-terminal cleaved domains in mitochondrial import of the yeast frataxin homolog, Yfh1p. Hum. Mol. Genet. 2001, 10, 259-269. [CrossRef] [PubMed]

85. Cho, S.J.; Lee, M.G.; Yang, J.K.; Lee, J.Y.; Song, H.K.; Suh, S.W. Crystal structure of Escherichia coli CyaY protein reveals a previously unidentified fold for the evolutionarily conserved frataxin family. Proc. Natl. Acad. Sci. USA 2000, 97, 8932-8937. [CrossRef]

86. Dhe-Paganon, S.; Shigeta, R.; Chi, Y.I.; Ristow, M.; Shoelson, S.E. Crystal structure of human frataxin. J. Biol. Chem. 2000, 275, 30753-30756. [CrossRef]

87. He, Y.; Alam, S.L.; Proteasa, S.V.; Zhang, Y.; Lesuisse, E.; Dancis, A.; Stemmler, T.L. Yeast frataxin solution structure, iron binding, and ferrochelatase interaction. Biochemistry 2004, 43, 16254-16262. [CrossRef]

88. Lee, M.G.; Cho, S.J.; Yang, J.K.; Song, H.K.; Suh, S.W. Crystallization and preliminary X-ray crystallographic analysis of Escherichia coli CyaY, a structural homologue of human frataxin. Acta Cryst. D Biol. Cryst. 2000, 56, 920-921. [CrossRef]

89. Musco, G.; Stier, G.; Kolmerer, B.; Adinolfi, S.; Martin, S.; Frenkiel, T.; Gibson, T.; Pastore, A. Towards a structural understanding of Friedreich's ataxia: The solution structure of frataxin. Structure 2000, 8, 695-707. [CrossRef] 
90. Nair, M.; Adinolfi, S.; Pastore, C.; Kelly, G.; Temussi, P.; Pastore, A. Solution structure of the bacterial frataxin ortholog, CyaY: Mapping the iron binding sites. Structure 2004, 12, 2037-2048. [CrossRef]

91. Roman, E.A.; Faraj, S.E.; Cousido-Siah, A.; Mitschler, A.; Podjarny, A.; Santos, J. Frataxin from Psychromonas ingrahamii as a model to study stability modulation within the CyaY protein family. Biochim. Biophys. Acta 2013, 1834, 1168-1180. [CrossRef]

92. Rasheed, M.; Jamshidiha, M.; Puglisi, R.; Yan, R.; Cota, E.; Pastore, A. Structural and functional characterization of a frataxin from a thermophilic organism. FEBS J. 2019, 286, 495-506. [CrossRef] [PubMed]

93. Popovic, M.; Sanfelice, D.; Pastore, C.; Prischi, F.; Temussi, P.A.; Pastore, A. Selective observation of the disordered import signal of a globular protein by in-cell NMR: The example of frataxins. Protein Sci. 2015, 24, 996-1003. [CrossRef] [PubMed]

94. Adinolfi, S.; Nair, M.; Politou, A.; Bayer, E.; Martin, S.; Temussi, P.; Pastore, A. The factors governing the thermal stability of frataxin orthologues: How to increase a protein's stability. Biochemistry 2004, 43, 6511-6518. [CrossRef]

95. Correia, A.R.; Pastore, C.; Adinolfi, S.; Pastore, A.; Gomes, C.M. Dynamics, stability and iron-binding activity of frataxin clinical mutants. FEBS J. 2008, 275, 3680-3690. [CrossRef]

96. Sanfelice, D.; Politou, A.; Martin, S.R.; De Los Rios, P.; Temussi, P.; Pastore, A. The effect of crowding and confinement: A comparison of Yfh1 stability in different environments. Phys. Biol. 2013, 10, 045002. [CrossRef] [PubMed]

97. Adrover, M.; Martorell, G.; Martin, S.R.; Urosev, D.; Konarev, P.V.; Svergun, D.I.; Daura, X.; Temussi, P.; Pastore, A. The role of hydration in protein stability: Comparison of the cold and heat unfolded states of Yfh1. J. Mol. Biol. 2012, 417, 413-424. [CrossRef]

98. Sanfelice, D.; Temussi, P.A. Cold denaturation as a tool to measure protein stability. Biophys. Chem. 2016, 208, 4-8. [CrossRef]

99. Gellera, C.; Castellotti, B.; Mariotti, C.; Mineri, R.; Seveso, V.; Didonato, S.; Taroni, F. Frataxin gene point mutations in Italian Friedreich ataxia patients. Neurogenetics 2007, 8, 289-299. [CrossRef]

100. Cossee, M.; Durr, A.; Schmitt, M.; Dahl, N.; Trouillas, P.; Allinson, P.; Kostrzewa, M.; Nivelon-Chevallier, A.; Gustavson, K.H.; Kohlschutter, A.; et al. Friedreich's ataxia: Point mutations and clinical presentation of compound heterozygotes. Ann. Neurol. 1999, 45, 200-206. [CrossRef]

101. Galea, C.A.; Huq, A.; Lockhart, P.J.; Tai, G.; Corben, L.A.; Yiu, E.M.; Gurrin, L.C.; Lynch, D.R.; Gelbard, S.; Durr, A.; et al. Compound heterozygous FXN mutations and clinical outcome in friedreich ataxia. Ann. Neurol. 2016, 79, 485-495. [CrossRef]

102. Pook, M.A.; Al-Mahdawi, S.A.; Thomas, N.H.; Appleton, R.; Norman, A.; Mountford, R.; Chamberlain, S. Identification of three novel frameshift mutations in patients with Friedreich's ataxia. J. Med. Genet. 2000, 37, E38. [CrossRef] [PubMed]

103. Bartolo, C.; Mendell, J.R.; Prior, T.W. Identification of a missense mutation in a Friedreich's ataxia patient: Implications for diagnosis and carrier studies. Am. J. Med. Genet. 1998, 79, 396-399. [CrossRef]

104. Forrest, S.M.; Knight, M.; Delatycki, M.B.; Paris, D.; Williamson, R.; King, J.; Yeung, L.; Nassif, N.; Nicholson, G.A. The correlation of clinical phenotype in Friedreich ataxia with the site of point mutations in the FRDA gene. Neurogenetics 1998, 1, $253-257$. [CrossRef] [PubMed]

105. Shan, Y.; Napoli, E.; Cortopassi, G. Mitochondrial frataxin interacts with ISD11 of the NFS1/ISCU complex and multiple mitochondrial chaperones. Hum. Mol. Genet. 2007, 16, 929-941. [CrossRef] [PubMed]

106. Clark, E.; Butler, J.S.; Isaacs, C.J.; Napierala, M.; Lynch, D.R. Selected missense mutations impair frataxin processing in Friedreich ataxia. Ann. Clin. Transl. Neurol. 2017, 4, 575-584. [CrossRef] [PubMed]

107. Correia, A.R.; Adinolfi, S.; Pastore, A.; Gomes, C.M. Conformational stability of human frataxin and effect of Friedreich's ataxia-related mutations on protein folding. Biochem. J. 2006, 398, 605-611. [CrossRef]

108. Bidichandani, S.I.; Ashizawa, T.; Patel, P.I. Atypical Friedreich ataxia caused by compound heterozygosity for a novel missense mutation and the GAA triplet-repeat expansion. Am. J. Hum. Genet. 1997, 60, 1251-1256.

109. Rufini, A.; Fortuni, S.; Arcuri, G.; Condo, I.; Serio, D.; Incani, O.; Malisan, F.; Ventura, N.; Testi, R. Preventing the ubiquitinproteasome-dependent degradation of frataxin, the protein defective in Friedreich's ataxia. Hum. Mol. Genet. 2011, 20, $1253-1261$. [CrossRef]

110. Faggianelli, N.; Puglisi, R.; Veneziano, L.; Romano, S.; Frontali, M.; Vannocci, T.; Fortuni, S.; Testi, R.; Pastore, A. Analyzing the Effects of a G137V Mutation in the FXN Gene. Front. Mol. Neurosci. 2015, 8, 66. [CrossRef]

111. Al-Mahdawi, S.; Pook, M.; Chamberlain, S. A novel missense mutation (L198R) in the Friedreich's ataxia gene. Hum. Mutat. 2000, 16, 95. [CrossRef]

112. Faraj, S.E.; Roman, E.A.; Aran, M.; Gallo, M.; Santos, J. The alteration of the C-terminal region of human frataxin distorts its structural dynamics and function. FEBS J. 2014, 281, 3397-3419. [CrossRef] [PubMed]

113. Faraj, S.E.; Gonzalez-Lebrero, R.M.; Roman, E.A.; Santos, J. Human Frataxin Folds Via an Intermediate State. Role of the C-Terminal Region. Sci. Rep. 2016, 6, 20782. [CrossRef] [PubMed]

114. Sacca, F.; Marsili, A.; Puorro, G.; Antenora, A.; Pane, C.; Tessa, A.; Scoppettuolo, P.; Nesti, C.; Brescia Morra, V.; De Michele, G.; et al. Clinical use of frataxin measurement in a patient with a novel deletion in the FXN gene. J. Neurol. 2013, 260, 1116-1121. [CrossRef] [PubMed]

115. Dobson, C.M. Principles of protein folding, misfolding and aggregation. In Seminars in Cell E Developmental Biology; Academic Press: Cambridge, MA, USA, 2004; Volume 15, pp. 3-16. [CrossRef]

116. Chaudhuri, T.K.; Paul, S. Protein-misfolding diseases and chaperone-based therapeutic approaches. FEBS J. 2006, $273,1331-1349$. [CrossRef] [PubMed] 